\title{
Phthiriasis palpebrarum
}

\author{
Georgios D Panos, ${ }^{1}$ Ioannis K Petropoulos, ${ }^{2}$ Doukas Dardabounis, ${ }^{3}$ Zisis Gatzioufas ${ }^{1}$
}

${ }^{1}$ Department of Ophthalmology, University Hospitals of Geneva, Geneva, Switzerland

${ }^{2}$ Department of Ophthalmology, Ophthalmological Center of

Rive, Geneva, Switzerland ${ }^{3}$ Department of Ophthalmology, University General Hospital of Alexandroupolis,

Alexandroupolis, Eastern Macedonia \& Thrace, Greece

\section{Correspondence to} Dr Georgios D Panos, gdpanos@gmail.com
To cite: Panos GD,

Petropoulos IK,

Dardabounis D, et al. BMJ

Case Rep Published online:

[please include Day Month

Year] doi:10.1136/bcr-2013-

009272

\section{DESCRIPTION}

A 61-year-old woman was admitted to the hospital because of itching, burning sensation and moderate pain of 3 months duration in her right eye. Her ophthalmologist diagnosed common anterior blepharitis and prescribed a combination of antibiotic and corticosteroid eye drops. Best corrected visual acuity was 20/20 in both eyes, intraocular pressure was $15 \mathrm{~mm} \mathrm{Hg}$ right eye and $14 \mathrm{~mm} \mathrm{Hg}$ left eye. Slit lamp examination revealed nits anchored to the eyelashes (figure 1). Moving insects were observed hanging from the eyelashes (red arrow, figure 1). We mechanically removed some of the eyelashes, including lice and nits, with the use of fine forceps and advised the patient to apply yellow oxide of mercury ointment $1 \%$ three times daily over the lid margins. Ten days later, the eyelashes were clear of all lice and nits. We continued the same treatment once daily for about 3 weeks. The patient was followed-up once every 15 days for 2 months. There was complete cure without any recurrence.

Phthiriasis palpebrarum is an uncommon condition in developed countries and appears in cases of bad hygiene. Sometimes this disease can be misdiagnosed as common blepharitis. There are a number of treatment options for phthiriasis palpebrarum including

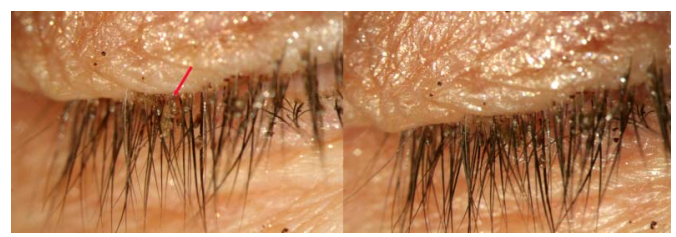

Figure 1 Slit lamp examination: Nits anchored to the eyelashes. A moving insect was observed hanging from an eyelash (red arrow). cryotherapy, argon laser photocoagulation, fluorescein eye drops $20 \%$, physostigmine $0.25 \%$, lindane $1 \%$, petroleum gel, yellow mercuric oxide ointment $1 \%$, malathion drops $1 \%$ or malathion shampoo $1 \%$, oral ivermectin and pilocarpine gel $4 \% .{ }^{1}$ However, the most popular and simplest treatment is direct removal of the parasites with forceps. ${ }^{1-3}$ Family members, sexual and close contacts should all be examined and treated appropriately, if necessary.

\section{Learning points}

- Phthiriasis palpebrarum is an uncommon condition in developed countries and appears in cases of bad hygiene.

- Sometimes this disease can be misdiagnosed as common blepharitis.

- There are a number of treatment options for phthiriasis palpebrarum, however the most popular and simplest is the direct removal of parasites with fine forceps.

\section{Competing interests None.}

Patient consent Obtained.

Provenance and peer review Not commissioned; externally peer reviewed.

\section{REFERENCES}

1 Jiang J, Shen T, Hong CY. A peculiar case of eye pruritus: phthiriasis palpebrarum initially misdiagnosed as common blepharitis. Int I Ophthalmol 2011;4:676-7.

2 Perlman HH, Fraga S, Medina M. Phthiriasis palpebrarum (phthiriasis ciliaris). J Pediatr 1956;49:88-90.

3 Ronchese $F$. Treatment of pediculosis ciliorum in an infant. $N$ Engl J Med 1953;249:897-8.

Copyright 2013 BMJ Publishing Group. All rights reserved. For permission to reuse any of this content visit http://group.bmj.com/group/rights-licensing/permissions.

BMJ Case Report Fellows may re-use this article for personal use and teaching without any further permission.

Become a Fellow of BMJ Case Reports today and you can:

- Submit as many cases as you like

- Enjoy fast sympathetic peer review and rapid publication of accepted articles

- Access all the published articles

- Re-use any of the published material for personal use and teaching without further permission

For information on Institutional Fellowships contact consortiasales@bmjgroup.com

Visit casereports.bmj.com for more articles like this and to become a Fellow 